\title{
Assessment of Current Technologies for Communition of Forest Residues
}

\author{
Dana L. Mitchell, Research Engineer
}

USDA Forest Service, Southern Research Station, Forest Operations Research Unit, 520 Devall Drive, Auburn, AL 36849, danamitchell@fs.fed.us

\author{
Written for presentation at the \\ 2005 ASAE Annual International Meeting \\ Sponsored by ASAE \\ Tampa Convention Center \\ Tampa, Florida \\ 17 - 20 July 2005
}

\begin{abstract}
Recent legislation and energy prices have led to an increased need for alternative energy sources. Biomass, including forest residues, is expected to replace a part of the nation's reliance on petroleum consumption. This paper provides an overview of existing literature related to the harvest, communition and transport of forest residues.
\end{abstract}

Past studies have investigated the systems associated with biomass harvesting. Researchers have explored whether to incorporate the biomass component with other forest product removals, or to harvest it in a separate entry.

Land managers do not have the tools to adequately assess the cost of biomass processing prior to treatments. Handling residue can be awkward due to the size and arrangement of the material. Dirt and rocks can contaminate residues and cause equipment repair problems or reduced utilization of the resource. These issues coupled with the problems of comparing existing production studies lead to some of the reasons why land managers have difficulty in assessing communition processing costs.

Logging residue and unmerchantable stems are expensive to transport without some sort of communition prior to transport. There are few studies available today that investigate some of the newer technology, such as horizontal grinders and slash bundling machines. Forest professionals could benefit from further research in this area to provide a means of more adequately determining production and costs of biomass harvesting.

Keywords. biomass, chippers, grinders, production, communition, forest residues, fuel, chunks.. 


\section{Introduction: Forest Residues as an Energy Source}

A recent US Department of Energy report (Perlack et al., 2005) has set a goal of displacing 30 percent or more of the country's present petroleum consumption with a sustainable supply of biomass. This goal would require approximately 1 billion dry tons of biomass feedstock per year. It is estimated that 64 million dry tons of residue would come from forest logging and site clearing operations, and 60 million dry tons of biomass would come from fuel treatment operations. According to the report, these amounts are sustainable from forestlands in the contiguous United States on an annual basis. This paper provides an overview of existing literature related to the harvest, communition and transport of forest residues.

In response to the Healthy Forests Act, some National Forests are removing unmerchantable material, including small diameter trees with no current market value. The many purposes of these operations include reducing the risk of wildfire, enhancing wildlife habitat, or increasing the vigor of the remaining trees in a stand. Most of these healthy forest contracts result in a cost to the federal government. Some of these treatments include mulching the unmerchantable stems with specialized equipment. The mulched material resembles chips and is left scattered in the forest. Other contracts pay contractors to cut and pile stems. When energywood mills are built, markets could appear where this unmerchantable material could be ground into chips or chunks and sold for hog fuel. Grinding operations could generate some revenue to help offset these healthy forest treatment costs. As a result, the potential reduced cost of treatments may allow more acres to be treated.

Logging residue typically consists of limbs and tops left over from logging operations. These residues may also include material that does not meet mill specifications, such as oversized logs, cut off cankers, or undesirable species. This material is sometimes spread over a tract, or piled on a deck, or ramp.

A Forest Inventory \& Analysis study in East Texas (Bentley and Johnson, 2003) found that 13 percent of total softwood volume and 24 percent of total hardwood volume is left as logging residue. The majority of this logging residue (75 percent) is in tops and limbs.

Forest residue processing is not limited to residues created by conventional tree-length product removals. Residues from chipping operations are another source of logging debris. When processing flail debris, the yield of fuel chips can average about $27 \%$ of the total volume of pulp and fuel chips (Baughman et al., 1990).

Roadside processing, such as chipping or grinding, may be an economical choice for forest residue comminution. A determination is needed whether to chip or grind the material; and whether to incorporate it into a conventional system or operate the residue processing separately. Equipment selection and operational systems are important areas to research to cost effectively enter the biomass market.

There have been a number of studies related to in-stand fuel reduction treatments, but very few have actually recovered the logging residue for utilization (e.g., Coulter et al., 2002). Studies in Denmark recovered in-woods chips using a chipper/chip shuttle system and a chipper/forwarder (Frisk, 2002), but this equipment is not commercially available in the United States. Production rates of chippers for pulp quality chips were widely studied in the 1980's. Production rates of grinders have not been documented in very many studies, but they are widely used, particularly tub grinders.

Some mills, such as the energy mill in Kettle Falls, Idaho, use milling by-products that have a moisture content of 50 percent. Forest residue typically has a moisture content of 
approximately 50 percent (wet basis). This processed residue could be delivered to energy mills while providing an additional forest product output, or could serve as a replacement forest product where mills have closed. The ability to provide a continuous supply of woody biomass to these mills may encourage the construction of more energy mills across the nation. Questions linger as to how to provide these materials in the most cost effective manner.

\section{Systems Overview}

\section{Harvest Systems}

Biomass processing can be integrated with the removal of other products, or it can be operated as a stand alone system. Conventional harvest operations can be modified in a number of ways to facilitate biomass removal.

A 1983 study in southern Alabama and southern Mississippi examined two methods of integrating biomass harvesting with the removal of conventional products (Watson et al., 1986; and Stokes et al., 1985). The one-pass method involved felling and skidding the energywood at the same time as the other products. The feller-buncher piled the energywood separately from the roundwood for the skidder. On the landing, roundwood was sorted and loaded tree length and the energywood was chipped. The two-pass method felled, skidded and chipped the energywood in the first pass, and a second operation was used to remove the merchantable roundwood. Both of these methods were compared to a conventional system that did not recover any energywood. The one-pass method had a higher utilization rate (harvested green tons per acre) than the other two methods because the limbs and tops from the merchantable roundwood were chipped along with the energywood. However, the one-pass method did not recover as much roundwood. More of the boles were left on the tops to facilitate feeding the chipper, which accounts for some of the roundwood volume loss. While the total cost of producing roundwood was similar between the one- and two-pass methods, the energywood production cost was significantly less with the one-pass method. Therefore, it is more economical to fell and skid energywood concurrently with other products than to fell and process it later.

If biomass is processed on an active site, the system must be balanced to avoid excessive, and costly, machine delays (Hartsough et al. 1994). If a loader is loading a truck, it is not available to feed the reduction equipment. If a skidder is needed to skid products and move tops and limbs from the delimbing area, the energywood processing equipment could be idled. If the logging equipment has moved on to another site, a biomass processor may require a support machine to move residue within reach of the loader arm, or if it isn't equipped, it may also require a loader of some type. Equipment mix and balance is a very important part of an efficient forest residue reduction operation. It is particularly important when working with a lowvalue product.

Adding a biomass removal component to a logging operation is not limited to conventional operations. Cut-to-length (CTL) systems can also include a biomass component. CTL systems typically do not move enough wood to adequately utilize a large, traditional chipper, so for equipment balance, a smaller chipper may be more appropriately sized. Bolding (2002) incorporated a Bandit Model 1850 Whole Tree Chipper ${ }^{11}$ into a CTL thinning operation to recover energywood. In this study, some operational characteristics were observed that could

\footnotetext{
${ }^{1}$ The use of trade or firm names in this publication is for reader information and does not imply endorsement of any product or service by the U.S. Department of Agriculture.
} 
help in selecting a grinder or chipper. The forwarder fed the chipper, as the chipper was not equipped with a loading arm. This feeding process resulted in a lot of machine interaction that could be lessened if the chipper had a drop feed. The forwarder was the production bottleneck in this CTL system because it was utilized at 85 percent, but had low production in terms of tons per productive machine hour than the other two pieces of equipment. The forwarder's productivity was impacted by the number of stops and average pile size being picked up on each turn. The total system cost reported (2002 \$) for harvesting the non-merchantable material was $\$ 25.70 /$ on-board ton. A second forwarder or a second shift on the forwarder could aid in balancing this system, but would increase the cost of the operation. So, the smaller chipper was appropriate for this harvesting system.

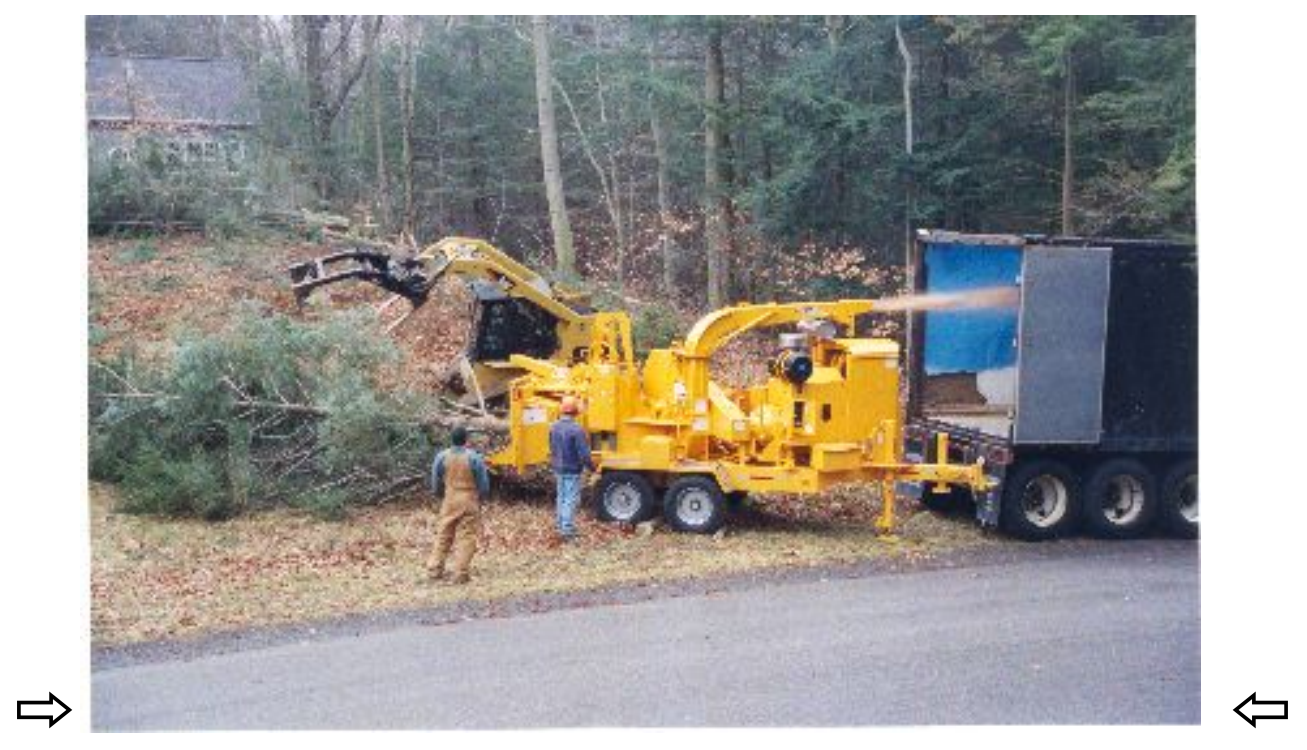

Figure 1. Bandit 1850 Whole Tree Chipper, shown with a separate loader (photo from Bandit Industries www.banditchippers.com)

System selection should also include considerations for move-in costs. Moving costs increase depending on the number of machines moved. The addition of a chipper or grinder increases the moving costs of a conventional system. Larger chippers are more expensive to move than smaller chippers (Björheden et al., 2003). Although, their higher moving costs can be somewhat minimized if they can be spread over larger unit sizes (Hartsough, 1990).

When biomass processing is not integrated with the removal of other products, the biomass must pay for all equipment used on the job and the transportation of the equipment to the job. If road work is needed, biomass revenue must also cover this expense. Today, delivered hog fuel prices of $\$ 20 /$ green ton are not uncommon. Unless the price of hog fuel increases, integrated harvesting of biomass may be the most economical option.

\section{Production Impacts}

The handling requirements of various types of logging residue may impact productivity or equipment selection. Where the slash includes larger tops, it is easier to handle resulting in higher productivity (Desrochers, 1995). Stems from pre-commercial thinning operations are typically longer than limbs and tops, which may also lead to higher productivity. If longer slash material is piled with fairly even ends, a grapple can pick up a fairly large payload, or "bite". Because of the shorter nature of limbs and tops, a grapple cannot handle the material as 
efficiently, even if it is piled. The smaller pieces fall out of the grapple if they are not held tightly in the middle, tops can dangle and fall out as the grapple is moved toward a processor. Anyone who has seen slash redistributed from a landing knows that skidder grapples are not very efficient at handling slash.

Some of the residue on a landing is not processed because it is intermingled with rocks and soil which could harm a chipper or grinder (Desrochers,1996). When slash is left in a tract in piles, the utilization may be less because operators have a tendency to work where the slash volume is the most concentrated (Desrochers, 1995).

A review of a few residue processing production studies reveals that direct comparisons are difficult. As shown in Table 1, the description of residues and methods of documenting productivity can vary widely. The studies compared in Table 1 do not include the entire cost of the harvesting operation, just the chipping portion of the operation.

Table 1. Production and Cost Estimates for Comminution of Forest Residues

\begin{tabular}{|c|c|c|c|c|c|}
\hline Reference & $\begin{array}{l}\text { Communition } \\
\text { Device }\end{array}$ & Type $^{a}$ & $\begin{array}{l}\text { Description of Forest } \\
\text { Residues }\end{array}$ & Productivity $^{b}$ & $\begin{array}{l}\text { Cost (PMH) } \\
\text { (US\$2002) }\end{array}$ \\
\hline $\begin{array}{l}\text { Bolding } \\
2002\end{array}$ & $\begin{array}{l}\text { Bandit } 1850 \\
\text { Whole Tree } \\
\text { Chipper }\end{array}$ & $\mathrm{M}$ & $\begin{array}{l}\text { Limbs and tops from } \\
\text { merchantable pine } \\
\text { and hardwood } \\
\text { thinning; and non- } \\
\text { merchantable trees } \\
0.5-4.0 \text { inches DBH. }\end{array}$ & $\begin{array}{l}20.24 \mathrm{gt}^{\mathrm{C}} / \mathrm{pmh} \\
\left(11.54 \mathrm{bdt}^{\mathrm{d}} / \mathrm{pmh}\right)\end{array}$ & $\begin{array}{l}\text { \$1.73/gt } \\
\left(\$ 3.04 / \mathrm{bdt}^{\mathrm{d}}\right)\end{array}$ \\
\hline \multirow{3}{*}{$\begin{array}{l}\text { Asikainen } \\
\text { and } \\
\text { Pulkkinen, } \\
1998\end{array}$} & $\begin{array}{l}\text { Evolution } \\
\text { 910R Drum } \\
\text { Chipper }\end{array}$ & $\mathrm{M}$ & \multirow{3}{*}{$\begin{array}{l}\text { Logging residues from } \\
\text { spruce-dominated } \\
\text { final fellings in Finland }\end{array}$} & $\begin{array}{l}11.510^{3} \\
\mathrm{~kg} / \mathrm{pmh} \text { (dry } \\
\text { mass) }\end{array}$ & $\begin{array}{l}\$ 11.38 / \\
\text { bdt }^{\mathrm{d}, \mathrm{e}}\end{array}$ \\
\hline & $\begin{array}{l}\text { MOHA } \\
\text { Chipper Truck }\end{array}$ & $\mathrm{S}$ & & $\begin{array}{l}4.710^{3} \mathrm{~kg} / \mathrm{pmh} \\
\text { (dry mass) }\end{array}$ & $\begin{array}{l}\$ 17.83 / \\
\text { bdt }^{\text {d,e }}\end{array}$ \\
\hline & $\begin{array}{l}\text { Morbark } 1200 \\
\text { Tub Grinder }\end{array}$ & $\mathrm{M}$ & & $\begin{array}{l}9.0-10.510^{3} \\
\mathrm{~kg} / \mathrm{pmh} \text { (dry } \\
\text { mass) }\end{array}$ & $\begin{array}{l}\$ 11.29 / \\
\text { bdt }^{\mathrm{d}, \mathrm{e}}\end{array}$ \\
\hline $\begin{array}{l}\text { Hartsough } \\
\text { et al., } 1994\end{array}$ & $\begin{array}{l}\text { Morbark } \\
\text { 60/36 Drum } \\
\text { Chipper }\end{array}$ & $\mathrm{M}$ & $\begin{array}{l}\text { Logging residues, } \\
\text { piled tops and larger } \\
\text { limbs, trees }<10- \\
\text { inches dbh }\end{array}$ & NA & $\begin{array}{l}\$ 5.46- \\
10.68 / \mathrm{bdt}^{\mathrm{d}}\end{array}$ \\
\hline
\end{tabular}

${ }^{\mathrm{a}} \mathrm{M}=$ Mobile, not self-propelled; $\mathrm{S}$ = Self-propelled

${ }^{\mathrm{b}} \mathrm{PMH}=$ Productive machine hour; $\mathrm{SMH}=$ Scheduled machine hour

${ }^{\mathrm{c}} \mathrm{gt}=$ green tons

${ }^{d}$ bdt $=$ bone dry ton

e conversions made by author for FIM (1998) to USD(2002); SMH to PMH; and $10^{\wedge} 3 \mathrm{~kg}$ to tons (US-short).

When logging residue is processed in a secondary operation many options are available and more are yet to be explored. For example, in a study using horizontal grinders, slash was prebunched along a road for later grinding. In steeper terrain or where ramp size is limited, slash can be pre-hauled to a centralized location for grinding before transport to the final destination (Rawlings et al., 2004). 


\section{Bundling - A New Technology}

New equipment technologies include bundlers. Various types of bundling machines exist in Europe. The first of such machines to be introduced in the United States is the John Deere 1490D Slash Bundler. This self-propelled machine compacts forest residues into wrapped bunches that can be easily handled with a forwarder or log loader. Production rates in the range of 5 - 24 bundles/hour have been achieved (Rummer et al., 2004). Slash loading and arrangement are among the stand characteristics that impact the production of the machine.

If unmerchantable stems are felled but not skidded concurrently with other products, some sort of piling is needed to cost effectively transport the material to roadside for processing at a later time (Johnson, 1989). Bundlers can be used to gather the logging residue and transport it to roadside. In Scandinavian countries, bundles are typically hauled intact to a storage facility rather than chipped at roadside. At the storage facility, the bundles are stacked and chipped as needed at the mills.

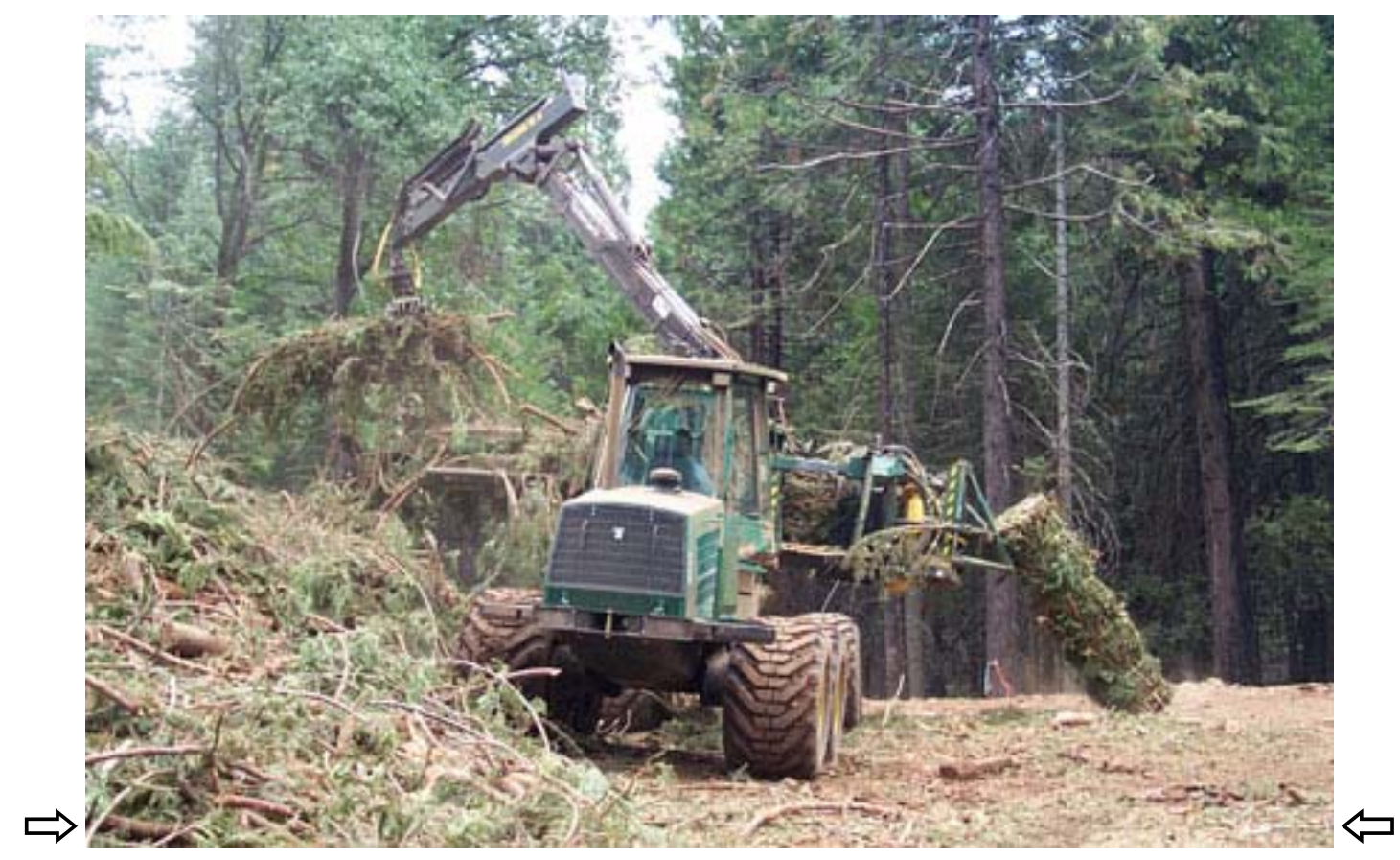

Figure 1. Timberjack 1490D Slash Bundler

(photo from Rummer et al., 2004)

\section{Transporting Biomass}

Transportation can be a large cost when considering biomass recovery. One of the problems with transporting biomass is densifying the material enough to make it economical to haul. When piled or loaded in the unprocessed form, there is a lot of area between the limbs and tops creating voids or air pockets that take up space on the load, but do not weigh anything. When biomass is processed into a denser form, it can be hauled more compactly and payloads can be increased. For example, at 50 percent moisture content, a chip van can hold 12.8 green tons of loose residues, but when the residues are chipped, the van can hold 25.3 green tons (Johnson, 
1989). Therefore, transportation of biomass is more efficient when some densification process precedes the haul. Some people refer to this as processing the material "close to the stump".

\section{Valuing Processed Residue}

How much is a load of residue worth? For discussion purposes, the price paid for the raw product at the final destination could be set as the value. This delivered price, less the costs to process and transport the raw product results in a balance amount that could be a positive number or a negative number. If the final number is positive, then it could represent profit (if not included in the processing costs) or it could represent the value of the residue before processing (stumpage value). If the final number is negative, it may represent an amount that a forest manager or landowner would have to pay to compensate a contractor for processing and transporting the hog fuel.

Why would someone pay to have residue removed from logging sites? Studies indicate that removing residue can reduce the costs of site preparation (Ragan et al., 1987). Removal can also reduce the fuel loading which can offset the cost of removal if compared to the costs of either suppressing a wildfire or implementing a site preparation burn. If clearing an area for real estate purposes, removal of the residue results in a more aesthetically pleasing environment where buyers can see further across a tract, often resulting in higher receipts to the land seller. Even if the entire cost of the comminution operation is not offset by any value received directly from the processed residue, the indirect benefits of increased revenue or reduced site preparation costs can make the operation profitable.

Forest residues are not easily compared to gas or oil because they have different handling properties than wood. Oil and gas can be delivered in pipes where valves can turn delivery off and on. Wood chips and chunks are hauled by trucks or rail, and are typically unloaded in a storage area. They are recovered from the storage area by a mechanical device such as a conveyor, blower or front-end loader. As long as the residues are in their original form and not further processed into syngas, the most likely energy source comparison may be coal. Coal has similar transportation pathways as wood, and can also be fired in a direct combustion process.

On average, coal has an energy value of $25 \mathrm{MMBtu} / \mathrm{ton}$. This energy value ranges depending on such factors as the cleanliness of the coal. The Energy Information Administration (EIA, 2005 ) listed the average price of coal to electricity generators in March, 2005, as \$1.51/MMBtu. Given the energy value of coal, the price of coal was $\$ 37.75 /$ ton.

Forest residues have an energy value of $17.5 \mathrm{MMBtu} /$ oven-dry ton. Some simple assumptions must be made to complete the forest residues to coal value comparison. Assuming that forest residues can be cut, skidded and processed for $\$ 11 /$ green ton and hauled for an additional $\$ 4.80 /$ green ton (with a 40 mile or less haul distance), the delivered price of forest residues would be $\$ 15.80 /$ green ton. Given a moisture content of $46 \%$ (wet basis), the delivered cost of an oven-dried ton would be $\$ 34.35$, or $\$ 1.96 / \mathrm{MMBtu}$. Based on these assumptions, wood costs $\$ 0.45 / \mathrm{MMBtu}$ more than coal. If the material is already severed and the communition costs only include skidding, processing and transport, the cost for the delivered wood could be reduced to $\$ 1.47 / \mathrm{MMBtu}$ which is less than the recent cost of oil. As the price of oil rises, comminuted wood may become more cost competitive.

\section{Discussions and Conclusions}

Additional research is needed to provide answers to the operational barriers of procuring forest residue for energy. Information regarding balancing equipment within an operational system could be useful for a contractor looking to expand a forest products operation to include 
energywood as an output. When more production data is available, forest managers and contractors will be able to more closely predict the costs of forest residue removal.

Many of the mills do not provide specifications for their hog fuel deliveries. Actual in-woods production data can provide the chunk and chip sizes from various chipping and grinding equipment which can aid in equipment selection if mills become more sensitive to the size of the material delivered.

It can be difficult to make comparisons on equipment productivity rates because the raw product can be so variable. Moisture content, species mix, seasonal drying, distribution of residue, and harvest systems are just a few of the factors that can make reported production rates highly variable and difficult to compare. Replicated studies are needed to provide an adequate comparison of equipment and provide a range of production rates. These comparisons and related data could be the basis for modeling fuel reduction chipping and grinding costs.

\section{References}

Asikainen A., P. Pulkkinen. 1998. Comminution of logging residues with Evolution 910R chipper, MOHA chipper truck, and Morbark 1200 tub grinder. Journal of Forest Engineering 9(1): 47-53.

Baughman, R. K., B. J. Stokes, W. F. Watson. 1990. Utilizing residues from in-woods flail processing. In: Stokes, B.J., ed. Proceedings of the International Energy Agency, Task VI, Activity 3 Workshop, "Harvesting Small Trees and Forest Residues"; 1990 May 28; Copenhagen, Denmark. Auburn, AL: U.S. Department of Agriculture, Forest Service, Southern Forest Experiment Station 1990: 21-30.

Bentley, J. W., T. G. Johnson. 2004. Eastern Texas harvest and utilization study, 2003. Resource Bulletin, SRS-97. Asheville, NC: U.S. Department of Agriculture, Forest Service, Southern Research Station. 28p.

Björheden, Rolf., T. Gullberg, J. Johansson. 2003. Systems analyses for harvesting small trees for forest fuel in urban forestry. Biomass and Bioenergy 24 (2003): 389-400.

Bolding, M. 2002. Forest fuel reduction and energy wood production using a cut-to-length/small chipper harvesting system. MS thesis. Auburn, Alabama: Auburn University, School of Forestry and Wildlife Sciences.

Bolding, M. C., B. L. Lanford. 2001. Forest fuel reduction through energy wood production using a small chipper/CTL harvesting system. [CD-ROM] In: Wang, Jingxin; Wolford, Michelle; and McNeel, Joe, eds. Appalachian hardwoods; managing change: Proceedings of the 24th Annual Council on Forest Engineering Meeting. Corvallis, OR: Council on Forest Engineering: 65-70.

Coulter, E., K. Coulter, T. Mason. 2002. Dry Forest Mechanized Fuels Treatment Trials Project. USDA Forest Service, Pacific Northwest and Intermountain Regions, National Fire Plan. Available at: www.theyankeegroup.com/mechfuels/DFMT Final Report.pdf. Accessed 23 April 2005.

Desrochers, L., D. Puttock, M. Ryans. 1995. Recovery of roadside residues using drum vhippers. TR-111. Forest Engineering Research Institute of Canada. March, 1995. 18 p.

Desrochers, L. 1996. Treatment of roadside delimbing areas. TN-248. Pointe-Claire, Quebec, Canada: FERIC.14 p.

EIA, 2005. Electric Power Monthly with data for April 2005. July 2005. Energy Information Administration, US Department of Energy. DOE/EIA-0226 (2005/07): 164p. Available at: www.eia.doe.gov/cneaf/electricity/epm/epm_sum.html. Accessed 14 July 2005. 
Frisk, K. 2002. Production of fuelchips in thinning stands in Denmark. May 21, 2002. Danish National Forest and Nature Agency. 7p.

Hartsough, B. R. 1990. Product/Harvesting options for agroforestry plantations in the San Joaquin Valley, California. ASAE Paper 90-7546. St. Joseph, MI: American Society of Agricultural Engineers. 23p.

Hartsough, B. R., J. F. McNeel, T. A. Durston, B. J. Stokes. 1994. Comparison of mechanized systems for thinning ponderosa pine and mixed conifer stands. ASAE Paper 94-7513. St. Joseph, MI: American Society of Agricultural Engineers. 20 p.

Johnson, L.R. 1989. Wood residue recovery, collection and processing. In Biomass Energy Project Development Guidebook, 11:1-71. Department of Energy, Bonneville Power Administration.

Miller, D. E., T. J. Straka, B. J. Stokes, W. Watson. 1987. Productivity and cost of conventional understory biomass harvesting systems. Forest Products Journal. 37(5): 39-43.

Perlack, R. D., L. L. Wright, A. Turhollow, R. L. Graham. 2005. Biomass as Feedstock for a Bioenergy and Bioproducts Industry: The Technical Feasibility of a Billion-Ton Annual Supply. ORNL/TM-2005/66. April, 2005. Oak Ridge, TN. Oak Ridge National Lab. 72 p.

Rawlings, C., B. Rummer, C. Seeley, C. Thomas, D. Morrison, H.-Sup Han, L. Cheff, D. Atkins, D. Graham, K. Windell. 2004. A study of how to decrease the costs of collecting, processing and transporting slash. Available at: www.mtcdc.org/downloads/SlashStudyFinal.pdf. Accessed 1 August 2005.

Ragan, J.R., W. F. Watson, B. J. Stokes. 1987. Impact of intensive utilization on regeneration operations. ASAE Paper 87-1564. St. Joseph, MI: American Society of Agricultural Engineers: $23 \mathrm{p}$.

Rummer, B., D. Len, O. O'Brien. 2004. Forest Residues Bundling Project, New Technology for Residue Removal. Auburn, Alabama: USDA Forest Service, Southern Research Station.

Stokes, B. J., W. F. Watson, William F.; I. W. Savelle. 1985. Alternate biomass harvesting systems using conventional equipment. In: Saucier, Joseph R., ed. Proceedings of the 1984 southern forest biomass workshop. Asheville, NC: U.S. Department of Agriculture, Forest Service: 111-114.

Watson, W.F., B.J. Stokes, I. W. Savelle. 1986. Comparisons of two methods of harvesting biomass for energy. Forest Products Journal 36(4): 63-68. 